\title{
Schematic Sustainability Assessment Model in Residential Area Using Residential Performance Management System (RPMS)
}

\author{
Heewon Lee ${ }^{1}$, Sanghyun $\mathrm{Lee}^{2}$ and Youngsuk $\mathrm{Kim}^{3 *}$ \\ ${ }^{1}$ Division of Architecture, Sunmoon University \\ ${ }^{2}$ College of Architecture, Myongji University \\ ${ }^{3}$ Depertmant of Architecture, Chungnam National University

\section{거주성능관리시스템(RPMS)을 이용한 주거지 지속가능성 평가모형 연구} \\ 이희 ${ }^{1}{ }^{1}$, 이상현 ${ }^{2}$, 김영석 ${ }^{* *}$ \\ ${ }^{1}$ 선문대학교 건축학부, ${ }^{2}$ 명지대학교 건축대학, ${ }^{3}$ 충남대학교 건축학과
}

\begin{abstract}
The concept of sustainability in residential area is closely related to the notion of amenity, livability, health and interchangeably used with the terms of urban growth management, urban regeneration, new urbanism, urban village movement, compact development, smart growth and the quality of residential environment.

Residential Performance Management System (RPMS This system is developed granted by 'Korea Institute of Construction \& Transportation Technology Evaluation and Planning' (KICTEP) during 2005-2008.)is a kind of decision making supportive program developed for the evaluation and assessment of various urban performances. It can be utilized for various purposes by many of urban related expert like planner, manager, etc.

This study investigate the schematic model for the applying the indicators of quality of residential environment developed by SDI (Seoul Development Institute) using RPMS.

요 약 주거지에서의 지속가능성은 어메니티, 거주성, 건강 등의 주제와 밀접한 관련이 있으며, 지속가능성의 개념 은 도시성장관리, 도시재생, 뉴 어바니즘, 압축개발, 스마트성장, 질좋은 주거환경의 개념과 상통하는 개념으로 사용되 고 있다. 거주성능관리시스템(RPMS)은 다양한 도시성능을 판단하고 평가할 수 있는 시스템으로, 도시관련 계획가나 관리자의 측면에서도 활용할 수 있다. 본 연구는 서울시정개발연구원에서 개발한 거주환경의 질 지표를 주거지의 지 속가능성 지표로하여 RPMS를 이용한 평가가능성을 과 적용방안을 모형으로 제시하였다.
\end{abstract}

Key Words : Sustainability, RPMS, Residential Area, Urban Performance, Evaluation

\section{Introduction}

\subsection{Background and purpose}

According to UN Bruntland Report, sustainable development is defined as "development that meets the needs of the present without compromising the ability of future generations to meet their own needs." For the sustainability of residential area, a lot of researches in various fields have been undergoing. One of the research fields is the evaluation and assessment related field. More specifically, developing assessment indicators (index) and computerized system for automated assessment are one of the research fields.

The concept of sustainability in residential area is closely related to the notion of amenity, livability, health and interchangeably used with the terms of urban growth

This work was supported by the Sun Moon University Research Grant of 2010

"Corresponding Author : Youngsuk Kim (kys3810@cnu.ac.kr)

Received December 28, 2010 Revised March 24, $2011 \quad$ Accepted April 07, 2011 
management, urban regeneration, new urbanism, urban village movement, compact development, smart growth and the quality of residential environment. According to recently issued report of SDI, "Indicators and Evaluations of the Quality of Residential Environments in Seoul" (2008), sustainability of residential area depend on the quality of residential environment.

Also, in relation to automated assessment system, Residential Performance Management System (RPMS) is developed by Industrial-Academia Cooperation Team of Myongji University granted by Korea Institute of Construction \& Transportation Technology Evaluation and Planning. (KICTEP) (2005-2008)

This study will suggest a schematic method for sustainability assessment model in urban residential area applying the indicators for the quality of residential environment as sustainability indicators and utilizing RPMS as automated assessment system.

\subsection{Scope and method}

Starting with the search of the theoretical articles related to the sustainability and quality of residential area, this study will select the appropriate existing indicators for the assessment of quality of residential environment. Descriptions of the characteristics and the RPMS system algorithm will be followed.

Then, for the applying the indicators to RPMS, a set of calculation formula for the extraction of indicator value and 2D representation schema for the system will be studied. Finally, the possibility of the application of the indicator values to the system will be suggested. Only quantifiable indicators can be used for this study.

\section{Sustainable development and indicators of quality of residential environment}

\subsection{Sustainable development}

Sustainable development is a pattern of resource use that aims to meet human needs while preserving the environment so that these needs can be met not only in the present, but also for future generations. It ties together concern for the carrying capacity of natural systems with the social challenges facing humanity. This means comprehensively considered development of land use, transportation, telecommunication, energy, socio-politics, environment, historical and cultural preservation and regeneration.

\subsubsection{Urban growth management}

Growth management is a set of techniques used by government to ensure that as the population grows that there are services available to meet their demands. These are not necessarily only government services. Other demands such as the protection of natural spaces, sufficient and affordable housing, delivery of utilities, preservation of buildings and places of historical value, and sufficient places for the conduct of business are also considered.

The application of growth management techniques are often governed by the development of a comprehensive plan. Generally, the plan can be prepared by these 6 criteria: consistency between related plans, concurrency between environmental development and SOC, compact urban development, affordable housing, preservation of historical and natural resources, economic development.

\subsubsection{Urban regeneration.}

Urban regeneration is a program of land re-development in areas of moderate to high density urban land use. Urban regeneration is a complex combination social, economic, planning, construction and management activities. These elements of urban regeneration are brought together to improve the social sustainability, economic stability and the infrastructure of a geographical location and so help improve the sustainability of the urban landscapeit occupies. It promotes population return, industrial activity, and revitalization in CBD area by suppressing the sprawl of metropolitan area to avoid its declination.

Consultation with local communities about urban regeneration plans has been recognized as being vital to the success of urban regeneration projects. This is because urban regeneration has direct links to, and affects directly, the communities living in the areas where regeneration is planned. Successful urban regeneration will not only work at the physical level but will result in successful, viable, vibrant and sustainable communities [7]. 


\subsubsection{New Urbanism.}

New Urbanism is an urban design movement that arose in the United States in the early 1980s and is a reaction to sprawl, based on planning and architectural principles working together to create human-scale, walkable communities. Its goal is to reform many aspects of real estate development and urban planning, from urban retrofits to suburban infill. New Urbanism can include (neo)traditional neighborhood design, transit-oriented development, and New Pedestrianism.

New urbanists support regional planning for open space, context-appropriate architecture and planning, and the balanced development of jobs and housing. They believe their strategies can reduce traffic congestion, increase the supply of affordable housing, and rein in urban sprawl. The Charter of the New Urbanism also covers issues such as historic preservation, safe streets, green building, and the redevelopment of brownfield land.

\subsubsection{Urban Village.}

An urban village is a concept of a settlement which is small enough to create a community in the truest sense of the word. Walking determines the size - a 10 minute walk from one side to the other. To provide a sufficiently large population to maintain a range of community facilities all within a walkable distance means the density of development must be high. An urban village is densely developed in the centre, with town squares and key community focal points, density eases awayfrom the centre, and the boundary of the village is marked by greenspace[8]. It refers to an urban form typically characterized by (1) Medium density development (2) Mixed use zoning (3)The provision of good public transit (4) An emphasis on urban design -particularly pedestrianization and public space.

Urban villages are seen to provide an alternative to recent patterns of urban development in Western cities, especially urban sprawl and modernism. They are generally purported to (1) Reduce car reliance and promote cycling, walking and transit use (2)Provide a high level of self containment (people working, recreating and living in the same area) (3) Help facilitate strong community institutions and interaction

\subsubsection{Smart Growth.}

Smart growth is an urban planning and transportation theory that concentrates growth in the center of a city to avoid urban sprawl; and advocates compact, transit-oriented, walkable, bicycle-friendly land use, including neighborhood schools, complete streets, mixed-use development with a range of housing choices Smart growth values long-range, regional considerations of sustainability over a short-term focus. Its goals are to achieve a unique sense of community and place; expand the range of transportation, employment, and housing choices; equitably distribute the costs and benefits of development; preserve and enhance natural and cultural resources; and promote public health.

Its specific topics can be organized into 7 issues.[9] (1) Community Quality of Life, (2) Design, (3) Economics, (4) Environment, (5) Health, (6) Housing, (7) Transportation

\subsection{Indicators of quality of residential environment}

According to the report of SDI, the sustainability of residential area is very closely related to the quality of residential environment, and this study will apply its suggested indicators for sustainability assessment in urban residential area. The suggested indicators are as below Table 1

[Table 1] Indicators of quality of residential environmen

\begin{tabular}{|c|c|c|}
\hline groups & $\begin{array}{l}\text { assessment } \\
\text { factors }\end{array}$ & physical environment indicators \\
\hline \multirow{4}{*}{ safety } & $\begin{array}{l}\text { traffic accident, } \\
\text { safety failure }\end{array}$ & $\begin{array}{l}\text {-hump } \\
\text {-upper } 20 \mathrm{~m} \text { width road } \\
\text {-hazardous, vehicle related, } \\
\text { industrial facility } \\
\text {-building age }\end{array}$ \\
\hline & crime incidence & $\begin{array}{l}\text {-entertainment for adult and } \\
\text { accommodation facility } \\
\text {-police station(stand) }\end{array}$ \\
\hline & fire incidence & $\begin{array}{l}\text {-housing density } \\
\text {-building age } \\
\text {-building coverage } \\
\text {-accessible route to site } \\
\text {-under } 4 \mathrm{~m} \text { with road } \\
\text {-fire station }\end{array}$ \\
\hline & $\begin{array}{l}\text { natural disaster } \\
\text { (flooding) }\end{array}$ & $\begin{array}{l}\text {-planned flood level } \\
\text {-underground residential }\end{array}$ \\
\hline
\end{tabular}




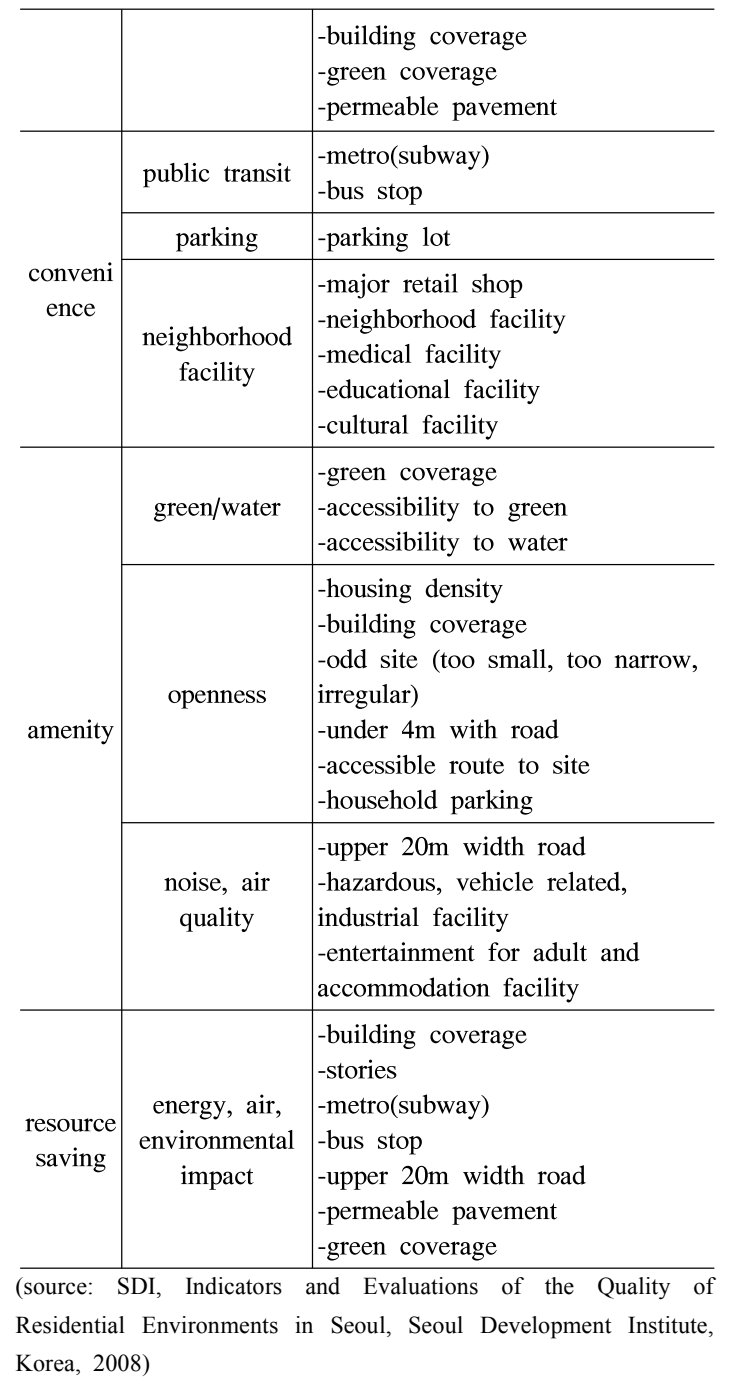

These physical environment indicators of quality of residential environment can be reorganized as of following 4 categories: (1)building/site (2) road/parking (3) land use (4) neighborhood facility. These indicators will be applied to RPMS Table 2.

\section{[Table 2] Physical environment indicators}

\begin{tabular}{c|l}
\hline category & \multicolumn{1}{|c}{ physical environment indicators } \\
\hline \multirow{3}{*}{$\begin{array}{c}\text { building/ } \\
\text { site }\end{array}$} & $\begin{array}{l}\text {-housing density/ -building coverage/ -stories/ } \\
\text {-building age/ -underground residential/ -odd } \\
\text { site (too small, too narrow, irregular)/ } \\
\text {-accessible route to site }\end{array}$ \\
\hline road/ & -under 4m with road/ -upper 20m width road/ \\
parking & -hump/ -parking lot \\
\hline
\end{tabular}

\begin{tabular}{l|l}
\hline land use & $\begin{array}{l}\text {-permeable pavement/ -green coverage/ } \\
\text {-accessibility to green/ -accessibility to water/ } \\
\text {-low land }\end{array}$ \\
\hline -metro(subway)/ -bus stop/ -major retail shop/ \\
neighb-orh \\
ood facility & $\begin{array}{l}\text {-eighborhood facility/ -medical facility/ } \\
\text {-hazardous, vehicle related, industrial facility/ } \\
\text {-entertainment for adult and accommodation } \\
\text { facility/ -police station(stand)/ -fire station }\end{array}$ \\
\hline (source: SDI, Indicators and Evaluations of the Quality of \\
Residential Environments in Seoul, Seoul Development Institute, \\
Korea, 2008)
\end{tabular}

\section{Residential Performance Management System (RPMS)}

RPMS is developed for the quantitative evaluation of various urban performances like amenity, residentiality, commerciality, safety, sustainability etc.(themes) RPMS represent existing residential area in specific 2D drawing, and carry an automated assessment (evaluation) of specific performance with given indicators for the area. Basically, the selection of theme is depends on the researcher's interest. Then he sets up quantifiable assessement criteria (indicators) and their relative weight. (this is another research area) Finally the assessmentprocess runs on parcel based information and urban infra information using GIS technology. During the assessmentprocess, enormous geographic and non geographic information is integrated, analyzed and reproduced according to the setting. The result can be used during the decision making process of urban planning. The general assessment process is as below Fig. 1.

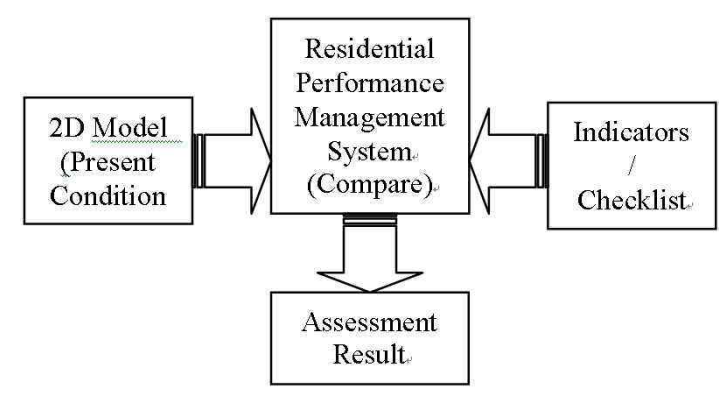

[Fig. 1] Assessment process of RPMS 


\subsection{Indicator oriented urban performance model}

For the assessment of specific urban performance, a lot of indicators can be considered, from hundreds to thousands. But almost all indicators can be classified into 2 query categories. Firstly, does the performance unit has proper internal properties for human staying (reside) in itself? Secondly, do the performance units have proper relational properties for human movement between themselves? These can be considered the 2 patterns for the indicator query like 5 patterns in English paragraph. So the indicator oriented urban performance model can be expressed [urban performance model $=$ Sum [performance unit (internal properties, relational properties)]\} [10].

Most of the internal properties are comprised of shape and function of performance unit like area, shape ratio, height etc.Most of the relational properties are comprised of (1) travel distance (TD), (2) change of direction (CD), (3) path history (PH), (4) visibility (VT) between two or more performance units[2].

\subsection{Urban representation model}

The representation of urban and architectural design means drawing of unit spaces and their relationship. Unit spaces can be represented by geometry of closed polygon, and relationship can be represented by geometry of poly-line. And for the automated assessment, these geometries should contain appropriate information. (properties) This information is comprised of internal properties and relational properties Table 3 . So the urban representation model can be expressed [urban representation model $=$ Sum (point, poly-line, polygon) $]$

[Table 3] Structure of urban performance model and urban representation model

\begin{tabular}{c|c|c|c}
\hline $\begin{array}{c}\text { human } \\
\text { behavior }\end{array}$ & $\begin{array}{c}\text { urban } \\
\text { performance } \\
\text { model }\end{array}$ & $\begin{array}{c}\text { urban representation } \\
\text { model }\end{array}$ & remarks \\
\hline $\begin{array}{c}\text { stay } \\
\text { (reside) }\end{array}$ & shape & closed polygon & \\
\cline { 2 - 4 } & function & associated text data & $\begin{array}{c}\text { TD (travel } \\
\text { distance) }\end{array}$ \\
\cline { 2 - 4 } $\begin{array}{c}\text { movemen } \\
\mathrm{t}\end{array}$ & $\begin{array}{c}\text { pD (change of } \\
\text { direction) }\end{array}$ & poly-line \& point & $\begin{array}{c}\text { movement } \\
\text { route }\end{array}$ \\
\cline { 2 - 4 } & $\begin{array}{c}\text { PH (path } \\
\text { history) }\end{array}$ & $\begin{array}{c}\text { poly-line \& closed } \\
\text { polygon }\end{array}$ & $\begin{array}{c}\text { movement } \\
\text { route \& }\end{array}$ \\
\hline
\end{tabular}

\begin{tabular}{l|l|c|r}
\hline & & & unit space \\
\cline { 2 - 4 } & VT (visibility) & $\begin{array}{c}\text { closed polygon \& } \\
\text { point }\end{array}$ & unit space \\
\hline (source: Sanghyun Lee, "An Automation-based Residential \\
Performance Evaluation System: Focused on the Quantifiable \\
Performance Index", Journal of the Architectural Institute of Korea, \\
AIK, Korea, 2008.08)
\end{tabular}

\subsection{Common model}

The indicator oriented urban performance model means: (1) unit space should have internal properties something like these, (2) two or more unit spaces should have relational properties something like those. Urban representation model shows unit spaces and route between themselves with geometry of point, poly-line and polygon.

These two models can be expressed with common model because they have common expression structure of \{Sum [unit space (internal properties, relational properties)]\}. Common model make it possible to compare these two models with RPMS.

\section{Schematic sustainability assessment model for RPMS}

\subsection{Urban representation model for existing or planned residential area}

For the representation of existing or planned residential area, all of the concerned locations, their connectivity and specific boundary should be included in a drawing. Point, poly-line and polygon represent location, connectivity and boundary respectively. Computer software like AutoCad can be utilized. All connectivity lines required to be segmented on their crossing nodes for the expediency of shortest path. This segmentation can be done utilizing GIS script.

Saved urban representation drawing will be retrieved by RPMS. A series of layers are displayed in the system screen with their own attribute table interlinked. This table can be modified for further data input.

The conversion of this representation model to common model means the conversion of the existing or planned condition to a set of unit spaces. This conversion will be done by manipulation of drawings and their tables. The existing or planned condition of residential area shown in common model is a series of table sets Fig. 2. 


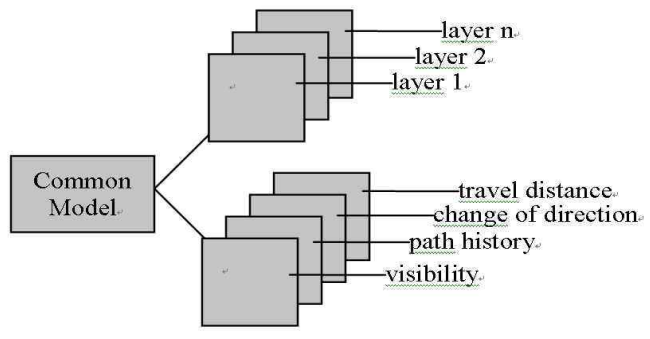

[Fig. 2] Common model in associated DB table

4.2 Indicator oriented urban performance model for the quality of residential environment

For the assessment of quality of residential environment (residential sustainability), not only representation model but also text based indicator oriented performance model should be converted into common model. Almost all indicators can be classified into 2 query patterns as mentioned in 3.1 .

For example of the first pattern, the performance indicator of "more than $30 \%$ of green space"can be calculated from the ratio of green area and total area. For this indicator, the relationship between them has no meaning, only their internal properties (areas) will be considered. This pattern will be fit into the expression of common model.

For the second pattern, almost all performance indicators can be described by the association of 4 kinds of query sentences as below: (1) travel distance between unit space, (2) the frequency of change of direction when moving, (3) the path history about where they are passing when moving, (4) visibility of the destination form

[Table 4] Schema for indicator value calculation, its model characteristics and RPMS applicability

\begin{tabular}{|c|c|c|c|c|c|}
\hline category & physical environment indicators & $\begin{array}{l}\text { indicator pattern (urban } \\
\text { performance model) }\end{array}$ & indicator value calculation & $\begin{array}{l}\text { 2D urban } \\
\text { representation model }\end{array}$ & $\begin{array}{c}\text { RPMS } \\
\text { applicability }\end{array}$ \\
\hline \multirow{7}{*}{$\begin{array}{l}\text { buildin } \\
\mathrm{g} / \text { site }\end{array}$} & housing density & internal property & no. of house/total area & closed polygon & $\mathrm{O}$ \\
\hline & building coverage & internal property & bd. area/site area & closed polygon & $\mathrm{O}$ \\
\hline & stories & internal property & avg. bd. story (incl. base) & point & $\mathrm{O}$ \\
\hline & building age & internal property & building age & point & $\mathrm{O}$ \\
\hline & underground residential & internal property & $\begin{array}{l}\text { underground residential fl. area/gross } \\
\text { fl. area }\end{array}$ & closed polygon & $\mathrm{O}$ \\
\hline & $\begin{array}{l}\text { odd site (too small, too narrow, } \\
\text { irregular) }\end{array}$ & internal property & $\begin{array}{l}\text { sum of (no. of under } 90 \text { sqm site area } \\
+ \text { no. of under } 5 \mathrm{~m} \text { site width) }\end{array}$ & closed polygon & $\mathrm{O}$ \\
\hline & accessible route to site & internal property & $\begin{array}{l}\text { no. of site having upper } 4 \mathrm{~m} \text { accessible } \\
\text { route/no. of all site }\end{array}$ & $\begin{array}{l}\text { closed polygon, } \\
\text { poly-line }\end{array}$ & $\mathrm{O}$ \\
\hline \multirow{4}{*}{$\begin{array}{c}\text { road/ } \\
\text { parking }\end{array}$} & under $4 \mathrm{~m}$ with road & internal property & $\begin{array}{l}\text { total length of under } 4 \mathrm{~m} \text { road/total } \\
\text { length of all road (incl. inside road of } \\
\text { housing block) }\end{array}$ & poly-line & $\mathrm{O}$ \\
\hline & upper $20 \mathrm{~m}$ width road & internal property & $\begin{array}{l}\text { total area of upper } 20 \mathrm{~m} \text { road/total area } \\
\text { (incl. } 50 \mathrm{~m} \text { buffer) }\end{array}$ & $\begin{array}{l}\text { closed polygon, } \\
\text { poly-line }\end{array}$ & $\mathrm{O}$ \\
\hline & hump & internal property & no. of hump/length unit $(\mathrm{km})$ & point & $\mathrm{O}$ \\
\hline & parking lot & internal property & no. of parking lot/gross fl. area & point & $\mathrm{O}$ \\
\hline \multirow{4}{*}{$\begin{array}{l}\text { land } \\
\text { use }\end{array}$} & permeable pavement & internal property & area/total area & closed polygon & $\mathrm{O}$ \\
\hline & green coverage & internal property & area/total area & closed polygon & $\mathrm{O}$ \\
\hline & accessibility to green and water & internal property & area/total area (incl. $500 \mathrm{~m}$ buffer) & closed polygon & $\mathrm{O}$ \\
\hline & low land & internal property & avg. elevation-planned flood elevation & closed polygon, point & $\mathrm{O}$ \\
\hline \multirow{7}{*}{$\begin{array}{l}\text { neighb- } \\
\text { orhood } \\
\text { facility }\end{array}$} & metro(subway) & relational property (TD) & actual distance from site & point, poly-line & $\mathrm{O}$ \\
\hline & bus stop & relational property (TD) & $\begin{array}{l}\text { no. of bus stop/area unit (sq. } \mathrm{km} \text { ) } \\
\text { (incl. } 500 \mathrm{~m} \text { buffer) }\end{array}$ & point, poly-line & $\mathrm{O}$ \\
\hline & major retail shop & $\begin{array}{l}\text { internal property } \\
\text { relational property (TD) }\end{array}$ & $\begin{array}{l}\text { area/population, actual distance from } \\
\text { site }\end{array}$ & $\begin{array}{l}\text { point, poly-line, closed } \\
\text { polygon }\end{array}$ & $\mathrm{O}$ \\
\hline & $\begin{array}{l}\text { neighborhood facility } \\
\text { medical facility } \\
\text { educational facility } \\
\text { cultural facility } \\
\end{array}$ & $\begin{array}{l}\text { internal property } \\
\text { relational property }(\mathrm{TD}, \\
\mathrm{CD}, \mathrm{PH})\end{array}$ & $\begin{array}{l}\text { area/population, actual distance from } \\
\text { site (incl. } 500 \mathrm{~m} \text { buffer) }\end{array}$ & $\begin{array}{l}\text { point, poly-line, closed } \\
\text { polygon }\end{array}$ & $\mathrm{O}$ \\
\hline & $\begin{array}{l}\text { hazardous, vehicle related, } \\
\text { industrial facility }\end{array}$ & $\begin{array}{l}\text { relational property }(\mathrm{TD}, \\
\text { VT) }\end{array}$ & area/total area (incl. $50 \mathrm{~m}$ buffer) & $\begin{array}{l}\text { point, poly-line, closed } \\
\text { polygon }\end{array}$ & $\mathrm{O}$ \\
\hline & $\begin{array}{l}\text { entertainment for adult and } \\
\text { accommodation facility }\end{array}$ & $\begin{array}{l}\text { relational property }(\mathrm{TD}, \\
\text { VT) }\end{array}$ & area/total area (incl. $50 \mathrm{~m}$ buffer) & $\begin{array}{l}\text { point, poly-line, closed } \\
\text { polygon }\end{array}$ & $\mathrm{O}$ \\
\hline & $\begin{array}{l}\text { police station(stand) } \\
\text { fire station }\end{array}$ & $\begin{array}{l}\text { relational property }(\mathrm{TD}, \\
\mathrm{CD})\end{array}$ & actual distance from site & point, poly-line & $\mathrm{O}$ \\
\hline
\end{tabular}


starting location when moving.This association of relational properties will be fit into the expression of common model.

For the application of indicators of quality of residential environment Table 1 to RPMS, the physical environment indicators Table 2 should be converted to fit common model. The indicator pattern and value calculation, 2D representational characteristics and RPMS applicability are summarized as below Table 4 .

\section{Conclusion}

The sustainability of urban residential area can be explained in view of the quality of residential environment according to various researches. And the assessment of the quality can be automated using computerized technique. Though this automated assessment has some limitations as of now, especially in the aspect of qualitative assessment, it must be a helpful and useful support for decision making process in case of enormous quantitative input data to consider.

This study suggests the possibility of automated assessment of the quality of residential environment using Residential Performance Management System (RPMS). Through utilizing existing assessment indicators and software, this study proposes new schematic model for the assessment. Actual application result will be followed this research according to the schematic model.

\section{References}

[1] Yongseok Kim, Heewon Lee, Hyerim Suh, "A Study on the Concept of Smart Growth and Its Implication", Journal of Daejeon-Chungnam Chapter of Architectural Institute of Korea, AIK, Korea, 2004.

[2] Sanghyun Lee, "An Automation-based Residential Performance Evaluation System: Focused on the Quantifiable Performance Index", Journal of the Architectural Institute of Korea, AIK, Korea, 2008.

[3] Seoul Development Institute, "Indicators and Evaluations of the Quality of Residential Environments in Seoul", SDI, Korea, 2008

[4] Chunri Fang, Sanghyun Lee, "Automation-based Urban

Performance Evaluation", Proceeding of Architectural Institute of Korea, AIK, Korea, 2008.

[5] Songjun Li, Sanghyun Lee, "A Study on the Evaluation of Residence Safety with the Use of Urban Performance Management System", Proceeding of Architectural Institute of Korea, AIK, Korea, 2008.

[6] Hyunhye Park, Jung-Hyung Lee, "A Study on Establishment of Conceptual Model for Sustainable Urban Planning and Design", Proceeding of Architectural Institute of Korea, AIK, Korea, 2001

[7] http://www.urbanregeneration.net/

[8] http://www.ice.org.uk/rtfpdf/BS-Urban\%20Villages.pdf

[9] http://www.smartgrowth.org

[10] Industrial-Academia Cooperation Team of Myongji University, "Residential Performance Management System - Interim Report of R \& D program for RIS", MOCT, 2008

Heewon Lee

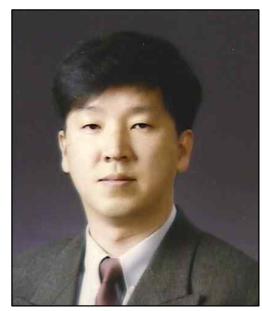

- Feb. 1989 : Seoul Univ., Dept. of Architecture, MS

- Feb. 2003 : Seoul Univ., Dept. of Architecture, Ph. D

- Mar. $1999 \sim$ current : Sunmoon Univ., Division. of Architecture, Associate Professor

$<$ Research Interests $>$

Architectural Planning \& Design, Urban Architecture GIS
Sanghyun Lee

[Regular member]

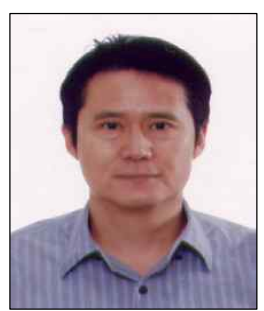

- Feb. 1986 : Seoul Univ., Dept. of Architecture, BS

- Apr. 1995 : The University of Michigan, M. Arch

- Mar. 1999 : Harvard University, Doctor of Design

- Mar. $2003 \sim$ current : Myungji Univ., College of Architecture, Associate Professor

$<$ Research Interests $>$

Design Computation, Application GIS 
Youngsuk Kim

[Regular member]

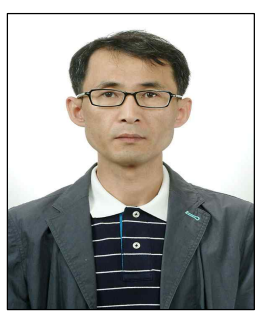

- Feb. 1989 : Seoul Univ., Dept. of Architecture, MS

- Feb. 2003 : Seoul Univ., Dept. of Architecture, Completion of Ph. D Course

- Mar.2004 current: Chungnam National Univ., Department. of Architecture, Associate Professor

$<$ Research Interests $>$

Architectural Planning \& Design, Ecological Architecture 